\title{
Fatty Acid Synthesis in Escherichia coli
}

\author{
BY V. A. KNIVETT AND JULIA CULLEN \\ Twyford Laboratories, Twyford Abbey Road, London, N.W. 10
}

(Received 31 August 1966)

\begin{abstract}
1. Fatty acid formation by cells of a strain of Escherichia coli has been studied in the exponential, post-exponential and stationary phases of growth. 2. During the exponential phase of growth, the metabolic quotient ( $m \mu$ moles of fatty acid synthesized/mg. dry wt. of cells/hr.) for each fatty acid in the extractable lipid was constant. 3. The newly synthesized fatty acid mixtures produced during this phase contained hexadecanoic acid (41\%), hexadecenoic acid (31\%), octadecenoic acid (21\%) and the $\mathrm{C}_{17}$-cyclopropane acid, methylenehexadecanoic acid (4\%). 4 . As the proportion of newly synthesized material increased, changes in the fatty acid composition of the cells during this period were towards this constant composition. 5. Abrupt changes in fatty acid synthesis occurred when exponential growth ceased. 6. In media in which glycerol, or $\mathrm{SO}_{4}{ }^{2-}$ or $\mathrm{Mg}^{2+}$, was growth-limiting there was a small accumulation of $\mathrm{C}_{17}$-cyclopropane acid in cells growing in the postexponential phase of growth. 7. Where either $\mathrm{NH}_{4}{ }^{+}$or $\mathrm{PO}_{4}{ }^{3-}$ was growth-limiting and there were adequate supplies of glycerol, $\mathrm{Mg}^{2+}$ and $\mathrm{SO}_{4}{ }^{2-}$, there was a marked accumulation of $\mathrm{C}_{17}$-cyclopropane acid and $\mathrm{C}_{19}$-cyclopropane acid appeared. 8. Under appropriate conditions the metabolic quotient for $\mathrm{C}_{17}$-cyclopropane acid increased up to sevenfold at the end of exponential growth. Simultaneously the metabolic quotients of the other acids fell. 9. A mixture of glycerol, $\mathrm{Mg}^{2+}$ and $\mathrm{SO}_{4}{ }^{2-}$ stimulated cyclopropane acid formation in resting cells.
\end{abstract}

Some factors affecting the fatty acid composition of the extractable lipid from a strain of Escherichia coli were described by Knivett \& Cullen (1965). The formation of the cyclopropane acids, methylenehexadecanoic acid and methyleneoctadecanoic acid, by the addition of the methyl group of $S$ adenosylmethionine across the double bond of hexadecenoic acid and octadecenoic acid, occurs on phosphatidylethanolamine (Hildebrand \& Law, 1964). An increase in the proportions of cyclopropane acids in cultures at later stages of growth has been observed in $E$. coli (Marr \& Ingraham, 1962; Law, Zalkin \& Kaneshiro, 1963; Knivett \& Cullen, 1965), Serratia marcescens (Law et al. 1963; Kates, Adams \& Martin, 1964), Agrobacterium tumefaciens (Law et al. 1963) and Lactobacillus arabinosus (Croom \& McNeill, 1961). Karkas, Türler \& Chargaff (1965) studied the fatty acid composition of nine methionine auxotrophs and three wild-type strains of $E$. coli grown in minimal and complete media for different periods of time.

In the present work we have studied fatty acid formation during the exponential, post-exponential and stationary phases of growth in a variety of media. The nutritional requirements for cyclopropane acid formation have been investigated.

\section{MATERIALS AND METHODS}

Growth of organisms. E. coli (Pfizer no. FD11396) was a gift from Chas. Pfizer Inc., Groton, Conn., U.S.A., and was maintained on slopes containing (per l.) $28 \mathrm{~g}$. of nutrient agar (Oxoid code no. CM3; Oxo Ltd., London, E.C. 4). The glycerol-inorganic salts medium contained the following A.R. reagents : glycerol, $\left(\mathrm{NH}_{4}\right)_{2} \mathrm{HPO}_{4}$ or $\mathrm{NH}_{4} \mathrm{Cl}, \mathrm{Na}_{2} \mathrm{SO}_{4}$, $10 \mathrm{H}_{2} \mathrm{O}, \mathrm{KH}_{2} \mathrm{PO}_{4}, \mathrm{MgSO}_{4}, 6 \mathrm{H}_{2} \mathrm{O}$ or $\mathrm{MgCl}_{2}, 6 \mathrm{H}_{2} \mathrm{O}$. The $\mathrm{pH}$ was adjusted to $\mathbf{7 . 0}$ with conc. $\mathrm{HCl}$. The following concentrations of constituents were tested, one of which was supplied in growth-limiting amounts (indicated *) and the others were supplied in excess: $\mathrm{SO}_{4}{ }^{2-}\left(0.05^{*}, 0 \cdot 1^{*}, 0.5\right.$, 0.75 and $1.5 \mathrm{~mm}) ; \mathrm{Mg}^{2+}\left(0.02^{*}, 0.04^{*}, 0.1\right.$ and $\left.0.2 \mathrm{mM}\right)$; $\mathrm{PO}_{4}{ }^{3-}\left(0 \cdot 22^{*}, 0 \cdot 33^{*}, 45 \cdot 2\right.$ and $\left.90 \cdot 4 \mathrm{mM}\right) ; \mathrm{NH}_{4}+(5 \cdot 0 *, 75 \cdot 8$ and $151.6 \mathrm{mM})$. The medium was usually made up in 101 . batches, boiled and then autoclaved for $1 \mathrm{hr}$. at $15 \mathrm{lb}$./in. ${ }^{2}$. Cells were grown at $37^{\circ}$ in the fermenter as described by Knivett \& Cullen (1965) and the $\mathrm{pH}$ was kept constant at $7 \cdot 0$. The volume of growth medium in the vessel was $1 \frac{1}{2}-$ 21. Regular observations of cell density were made throughout growth and larger samples (40-80 ml.) were withdrawn at appropriate intervals for fatty acid analysis. The volume of sample was small enough to permit all the samples to be removed without appreciably altering the growth conditions in the fermenter. In other experiments cells were grown in 21 . Erlenmeyer flasks containing $80 \mathrm{ml}$. of medium and incubated at $37^{\circ}$ for 18 or $42 \mathrm{hr}$. on a rotary shaker. The medium contained $14.6 \mathrm{~mm}-\mathrm{KH}_{2} \mathrm{PO}_{4}$, 


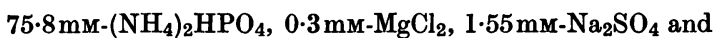
54.4mM-glycerol except where stated and was adjusted to $\mathrm{pH} 7.0$ with conc. $\mathrm{HCl}$ before autoclaving.

Extraction of lipid from the cells. The samples (usually 5-30mg. dry wt. of cells) were centrifuged for $20 \mathrm{~min}$. at $10^{4} \mathrm{~g}$ and the centrifuge tube was inverted, drained and wiped dry with a paper tissue. The pad of cells was made into a slurry with $10 \mathrm{ml}$. of methanol and extracted at $60^{\circ}$ for $10 \mathrm{~min}$. The insoluble material was separated by centrifuging and the extract evaporated to dryness, dissolved in chloroform, filtered and evaporated to dryness in a small stoppered tube. On such small samples of cells, further extraction with solvents (Knivett \& Cullen, 1965) yielded negligible amounts of lipid.

Interesterification of the lipid. Dry lipid (0.25-5mg.) was dissolved in methanol $(0 \cdot 1 \mathrm{ml}$.) containing boron trifluoride $\left(65 \mathrm{~g} . / \mathrm{l}\right.$.) and heated at $60^{\circ}$ in a water bath for $30 \mathrm{~min}$., immediately after which water $(0.1 \mathrm{ml}$.) was added. The methyl esters were extracted with light petroleum (b.p. $\left.30^{\circ}-40^{\circ}\right)(0 \cdot 1 \mathrm{ml}$.) and the lower aqueous layer was discarded.

Gas-liquid chromatography. The separations were performed as described by Knivett \& Cullen (1965). A selfdischarging capillary pipette (about $1 \mu$ l. capacity) was attached to a magnetic pipette that could be introduced on to the column via a closed injection system (W. G. Pye Ltd., Cambridge). The capillary was dipped into a solution of methyl esters and the volatile solvent allowed to evaporate in air, so that the methyl esters were concentrated at the tip of the capillary. A large solvent peak was thus avoided and the base line was more stable. An electronic integrator (Chromolog; George Kent Ltd., Luton, Bedfordshire) measured the peak areas.

Formation of cyclopropane acid by resting cells. Cells were grown in the fermenter in a medium containing $54.4 \mathrm{~mm}-$ glycerol, $151.6 \mathrm{mM}^{-\mathrm{NH}_{4}}{ }^{+}, 0.75 \mathrm{mM}_{-} \mathrm{SO}_{4}{ }^{2-}, 0.1 \mathrm{mM}-\mathrm{Mg}^{2+}$, sufficient $\mathrm{HCl}$ to bring the $\mathrm{pH}$ to $\mathbf{7 . 0}$ and growth-limiting amounts of $\mathrm{PO}_{4}{ }^{3-}(0.33 \mathrm{~mm})$. Growth was allowed to continue until $50 \mathrm{~min}$. after the end of exponential growth and $1100 \mathrm{ml}$. of culture was harvested by centrifuging. The cells were suspended in $150 \mathrm{ml}$. of $0.1 \mathrm{M}$-imidazole-HCl buffer (pH 7.0). Portions $(25 \mathrm{ml}$.) of this suspension were incubated at $37^{\circ}$ on a rotary shaker for $5 \mathrm{hr}$. in a final concentration of $45 \mathrm{~mm}$-imidazole-HC] buffer $(\mathrm{pH} 7 \cdot 0)$, $0.33 \mathrm{mM}_{-} \mathrm{MgCl}_{2}, 1.8 \mathrm{mM}_{-} \mathrm{SO}_{4}{ }^{2-}$ and $20 \mathrm{~mm}$-glycerol, except where stated. The cells were then harvested and the fatty acids analysed as described above.
Calculation of results. (a) Cell density (mg. dry wt. of cells per 1.) was plotted as $\log _{2}$ (cell density) against time (Monod, 1949). The end of exponential growth appeared as an obvious deviation from the straight line and the time at which this occurred could be estimated to within a few minutes (Fig. 3a). An increase of one unit on the ordinate scale represented a doubling of cell density and the doubling time $\left(t_{d}\right)$ was calculated from the slope of the straight line.

(b) The specific growth rate (S.G.R.) of the cells is the rate of increase of cell concentration (mg. dry wt. of cells/1.) per unit concentration of organism and is related to the doubling time by the following equation (Herbert, Elsworth \& Telling, 1956):

$$
\text { S.G.R. }=\frac{\mathrm{d} D}{\mathrm{~d} T} \cdot \frac{1}{D}=\frac{\mathrm{d}\left(\log _{\mathrm{e}} D\right)}{\mathrm{d} T}=\frac{\log _{\mathrm{e}} 2}{t_{d}}
$$

where $T$ is time, $D$ is cell density (mg. dry wt. of cells/l.) and $t_{d}$ is doubling time.

After the end of exponential growth the S.G.R. was no longer constant and accordingly was calculated from the relationship:

$$
\text { S.G.R. }=\frac{\Delta D}{\Delta T} \cdot \frac{1}{D_{m}}
$$

where $\Delta T=T_{2}-T_{1} ; \Delta D=D_{2}-D_{1}, D_{2}$ and $D_{1}$ are the cell densities at times $T_{2}$ and $T_{1}$ respectively and $D_{m}$ is the mean cell density between $D_{1}$ and $D_{2}$.

(c) The extractable lipid amounted to $6 \cdot 5 \pm 1 \%$ of the dry weight of the cells (Knivett \& Cullen, 1965). Of this material about $85 \%$ was phospholipid, which in turn contained about $65 \%$ of esterified fatty acid. We have therefore assumed that the fatty acid content of the cells remained constant in these experiments and that it amounted to one-thirtieth of the dry weight of the cells. The total amount of fatty acid/l. of culture was calculated by dividing the total amount of cells/l. by 30. From the percentage composition of the fatty acid/l., the concentration $(A)$ of each fatty acid (m $\mu$ moles/l.) was calculated.

(d) The relationship between fatty acid synthesis and cell growth was found by plotting, for each fatty acid, total fatty acid/1. (A) against cell density/l. (D) (Fig. 4). The slope of the straight-line plot $(\Delta A \mid \Delta D)$ represents the fatty acid synthesized (m $\mu$ moles)/mg. of new cell material formed (Table 1).

(e) The total fatty acid synthesized [ $\Sigma(\Delta A / \Delta D)]$ per mg. of new cell material was the sum of the $\Delta A / \Delta D$ values for

\section{Table 1. Fatty acid synthesis by exponentially growing cells}

Cells were grown in the fermenter at $37^{\circ}$ and samples were taken at intervals during the exponential phase of growth; the fatty acids were analysed as described in the Materials and Methods section. Several concentrations of medium constituents were tested (see the Materials and Methods section). The values quoted are the mean \pm s.D. for 22 experiments. The doubling time of the cells was $61 \mathrm{~min} . \pm$ s.D. (6).

\section{Fatty acids}

Fatty acid synthesized (m $\mu$ moles/mg. of new cell material formed)

Average composition of newly synthesized fatty acid (\%)

Metabolic quotient ( $m \mu$ moles of fatty acid synthesized/mg. dry wt. of cells/hr.)

$\begin{array}{cccc}16: 1 & 16: 0 & 17: 0 \nabla & 18: 1 \\ 40 \pm 5 \cdot 8 & 52 \cdot 6 \pm 3 \cdot 8 & 5 \cdot 0 \pm 1 \cdot 9 & 24 \cdot 6 \pm 2 \cdot 4 \\ 31 & 41 & 4 & 21\end{array}$

$27 \cdot 4 \pm 5 \cdot 1 \quad 36 \cdot 1 \pm 3 \cdot 9 \quad 3 \cdot 4 \pm 1 \cdot 5 \quad 16 \cdot 0 \pm 2 \cdot 7$ 
each fatty acid. The percentage of a single fatty acid $\left(A^{\prime}\right)$ in this mixture was (Table 1):

$$
\frac{\Delta A^{\prime} / \Delta D}{\Sigma(\Delta A / \Delta D)} \times \frac{1}{100}
$$

(f) The metabolic quotient $(q)$ of fatty acid synthesis is the rate of increase of fatty acid per unit concentration of organisms at $37^{\circ}(\mathrm{m} \mu$ moles of fatty acid synthesized $/ \mathrm{mg}$. dry wt. of cells $/ \mathrm{hr}$. at $37^{\circ}$ ):

$$
q=\frac{\Delta A}{\Delta T} \cdot \frac{1}{D_{m}}
$$

where $A$ is concentration of fatty acid (m $\mu$ moles/l.) and $\Delta A=A_{2}-A_{1}$, where $A_{2}$ and $A_{1}$ are the concentrations of fatty acid at times $T_{2}$ and $T_{1}$ respectively.

Since samples for fatty acid analysis were not taken at regular intervals, and to take small enough values for $\Delta T$ (for convenience $15 \mathrm{~min}$. intervals for $\Delta T$ were chosen), it was necessary to plot two graphs, firstly cell density (mg. dry wt. of cells/l.) against time and secondly fatty acid concentration ( $m \mu$ moles of fatty acid/l.) against time. The cell density and corresponding fatty acid concentrations could be read off at $15 \mathrm{~min}$. intervals and $(\Delta A / \Delta T) /-$ $\left(1 / D_{m}\right)$ could be calculated. During the exponential phase, where S.G.R. is constant, $q=$ S.G.R. $\times(\Delta A \mid \Delta D)$.

\section{RESULTS}

Effect of growth-limiting nutrients on cyclopropane acid formation in stationary-phase cells. $\boldsymbol{E}$. coli cells were grown up to the stationary phase in the glycerol-inorganic salts medium containing a range of concentrations of $\mathrm{SO}_{4}{ }^{2-}(0-0.3 \mathrm{mM}), \mathrm{Mg}^{2+}$ $(0-0 \cdot 2 \mathrm{~mm})$ and glycerol $(0-109 \mathrm{mM})$. The yield of cells was directly proportional to $\mathrm{SO}_{4}{ }^{2-}$ concentration up to $\mathbf{0 . 2 m M}$, to $\mathrm{Mg}^{2+}$ concentration up to $0.06 \mathrm{~mm}$ and to glycerol concentration up to $30 \mathrm{~mm}$. Under growth-limiting conditions the formation of 1g. dry wt. of cells required $160 \mu$ moles of $\mathrm{SO}_{4}{ }^{2-}$ (16mg. of sulphuric acid), $50 \mu$ moles of $\mathrm{Mg}^{2+}$ (1.2 mg. of magnesium) and $24.4 \mathrm{~m}-\mathrm{moles}$ of glycerol (2.1 g.)

Cells grown in growth-limiting concentrations of $\mathrm{SO}_{4}{ }^{2-}(<0.16 \mathrm{mM})$, or $\mathrm{Mg}^{2+}(<0.06 \mathrm{mM})$ or glycerol $(<30 \mathrm{~mm}$ ), contained an average of $4 \cdot 1 \%, 5 \cdot 7 \%$ and $8 \%$ respectively of $17: 0 \nabla^{*}$ in the fatty acids of the extractable lipid, and only traces of 19:0 $\mathrm{V}$. Cyclopropane acid formation was increased sharply when the concentration of $\mathrm{SO}_{4}{ }^{2-}$ (Fig. 1) or glycerol (Fig. 2a) or $\mathrm{Mg}^{2+}$ (Fig. 2b) was increased above growth-limiting concentrations, provided that the medium contained more than $0.2 \mathrm{mM}^{-\mathrm{SO}_{4}}{ }^{2-}, 0.06$ $\mathrm{mM}-\mathrm{Mg}^{2+}$ and $30 \mathrm{~mm}$-glycerol. Fig. 1 also shows that a longer incubation time favoured cyclopropane acid formation. In contrast with the above results,

* Abbreviations: the figure before the colon is the number of carbon atoms in the fatty acid and the figure after the colon is the number of double bonds; $\nabla$ indicates a saturated cyclopropane ring.

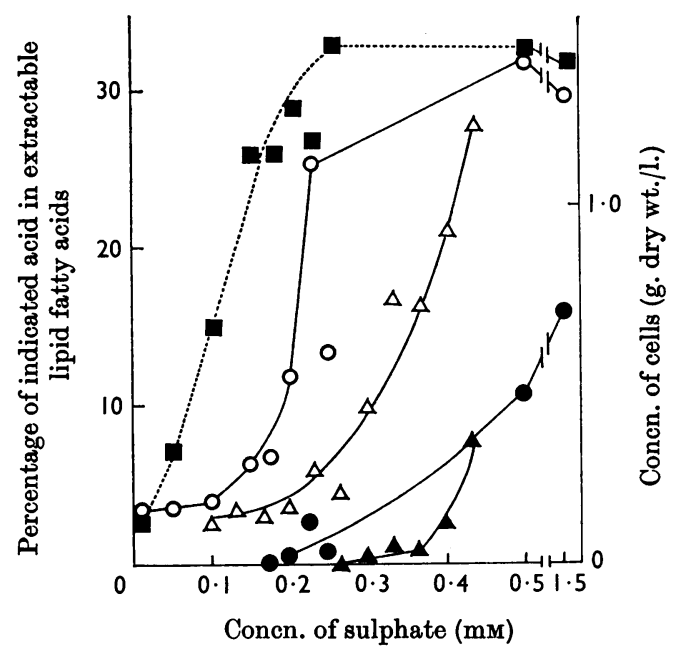

Fig. 1. Effect of sulphate concentration and time of incubation on cyclopropane acid formation in stationary-phase cells grown in glycerol-inorganic salts medium at $37^{\circ}$ in swirled flasks: percentages of 17:0 $\nabla$ acid (open symbols) and 19:0 $\nabla$ acid (solid symbols) in the extractable lipid fatty acids at $18 \mathrm{hr} .(\Delta, \Delta)$ and $42 \mathrm{hr}$. $(O, \bullet)$. Cell concentration after $42 \mathrm{hr}$. ( $\square$ ).

cells grown in growth-limiting amounts of either $\mathrm{NH}_{4}{ }^{+}(<6 \mathrm{mM})$ or $\mathrm{PO}_{4}{ }^{3-}(<0.128 \mathrm{mM})$ contained high proportions of cyclopropane acids. Fatty acid from cells grown in the presence of low concentrations of $\mathrm{PO}_{4}{ }^{3-}(0.001-0.128 \mathrm{~mm})$ contained: $29-32 \%$ of $17: 0 \nabla ; 3-6.5 \%$ of $19: 0 \nabla ; 2-3 \%$ of $16: 1$; $2 \cdot 5-6 \%$ of $18: 1 ; 47-51 \%$ of $16: 0$, and, in the presence of low concentrations of $\mathrm{NH}_{4}+(0.2-6 \mathrm{mM})$, contained $17-33 \%$ of $17: 0 \nabla$ and $0-11 \%$ of $19: 0 \nabla$.

Synthesis of fatty acids by growing cells. Cells were grown in the fermenter and samples were taken at intervals during growth for measurement of cell density and analysis of fatty acids. One of the constituents of the growth medium was restricted to a convenient growth-limiting amount and the others were supplied in excess. Depending on the amount of growth-limiting constituent supplied, bacterial densities at the end of exponential growth of up to $860 \mathrm{mg}$. dry wt. of cells/l. were reached. In 22 experiments the mean of doubling time was $61 \mathrm{~min} . \pm$ S.D. 6 and the S.G.R. for the exponential phase was $0.69 \mathrm{hr}^{-1}$. The end of exponential growth was sharply defined and could be estimated to within a few minutes. Because this point was significant in that marked changes in fatty acid metabolism occurred, it is convenient to examine the results under two headings, exponential and post-exponential phases of growth (Fig. 3). Postexponential growth continued for some time, in certain cases for several hours, and the transition 


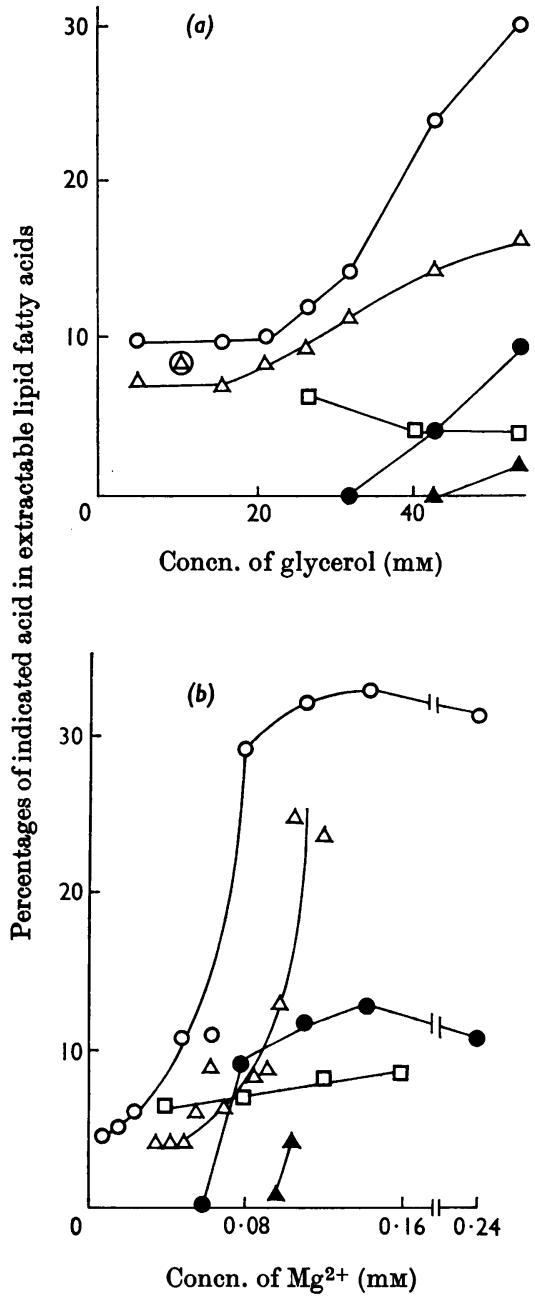

Fig. 2. Effect of a range of concentrations of glycerol, magnesium and sulphate on cyclopropane acid formation in stationary-phase cells grown at $37^{\circ}$ in glvcerol-inorganic salts medium for $18 \mathrm{hr}$. in swirled flasks: percentages of 17:0 $\nabla$ acid (open symbols) and 19:0 $\nabla$ (solid symbols) in the extractable lipid fatty acids. (a) The medium contained a range of glycerol concentrations with: $1.55 \mathrm{~mm}-\mathrm{Na}_{2} \mathrm{SO}_{4}$ and $0.2 \mathrm{mM}-\mathrm{MgCl}_{2}(\mathrm{O}, 0) ; 0.51 \mathrm{~mm}-\mathrm{Na}_{2} \mathrm{SO}_{4}$ and $0.2 \mathrm{~mm}$ $\mathrm{MgCl}_{2}(\Delta, \Delta) ; 0.51 \mathrm{~mm}-\mathrm{Na}_{2} \mathrm{SO}_{4}$ and $0.04 \mathrm{~mm}-\mathrm{MgCl}_{2}$ ( $\square$ ). (b) The medium contained a range of $\mathrm{MgCl}_{2}$ concentrations

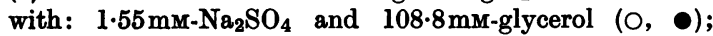

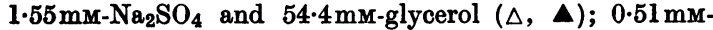
$\mathrm{Na}_{2} \mathrm{SO}_{4}$ and $27 \cdot 2 \mathrm{~mm}$-glycerol ( $\square$ ).

between post-exponential and stationary phases of growth was ill-defined. The main fatty acids considered were 16:1, 16:0,17:0 $\nabla$ and 18:1;19:0 $\nabla$ was included where more than trace amounts occurred, but other fatty acids usually present in

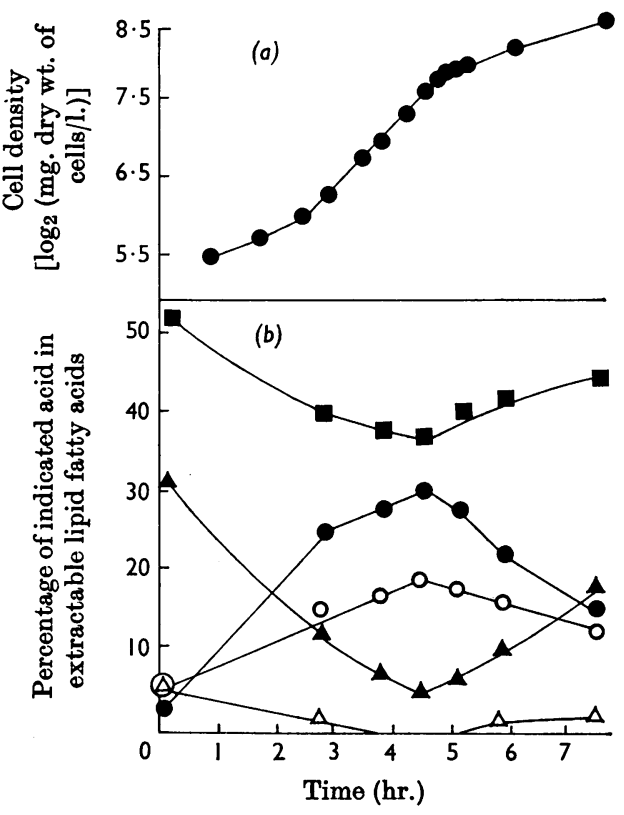

Fig. 3. Changes in the fatty acid composition of the extractable lipid fatty acids from cells sampled during growth in a phosphate-limiting medium. (a) Cell density: $\log _{2}$ (mg. dry wt. of cells/l.). (b) Percentages of 16:1 acid $(\bullet), 16 \cdot 0$ acid $(\square), 17: 0 \nabla$ acid $(\Delta), 18: 1$ acid $(O)$ and 19:0 $\nabla$ acid $(\Delta)$. The medium contained $0.75 \mathrm{mM}^{-\mathrm{SO}_{4}}{ }^{2-}, 54 \cdot 4 \mathrm{~mm}$-glycerol, $151.6 \mathrm{mM}^{-\mathrm{NH}_{4}}{ }^{+}, 0.1 \mathrm{mM}-\mathrm{Mg}^{2+}$ and $0.33 \mathrm{mM}-\mathrm{PO}_{4}{ }^{3-}$.

only small amounts were not included (e.g. 14:0, 18:0).

Exponential phase. The amount $(A)$ of each fatty acid/1. of culture was plotted against cell density $(D)$ as in Fig. 4. During exponential growth a straight-line plot was obtained for each of the main fatty acids in all experiments, indicating that the synthesis of fatty acid and of cell material increased in a constant proportion. In Fig. 4, the slope of the lines during exponential growth corresponded to $44 \mathrm{~m} \mu$ moles of $16: 1,53 \mathrm{~m} \mu$ moles of $16: 0,4 \mathrm{~m} \mu$ moles of $17: 0 \nabla$ and $22 \mathrm{~m} \mu$ moles of $18: 1$ synthesized $/ \mathrm{mg}$. of new cell material formed. In a series of experiments (Table 1) in which $\mathrm{SO}_{4}{ }^{2-}, \mathrm{Mg}^{2+}$, glycerol, $\mathrm{NH}_{4}{ }^{+}$or $\mathrm{PO}_{4}{ }^{3-}$ was made growth-limiting, there was an average of $40 \mathrm{~m} \mu$ moles of $16: 1,53 \mathrm{~m} \mu$ moles of 16:0, $5 \mathrm{~m} \mu$ moles of $17: 0 \nabla$ and $25 \mathrm{~m} \mu$ moles of 18: 1 synthesized $/ \mathrm{mg}$. of new cell material formed; 19:0 $\nabla$ was not synthesized during the exponential phase. From these values of $\Delta A / \Delta D$ the composition of newly formed fatty acid was calculated to be $31 \%$ of $16: 1,41 \%$ of $16: 0,4 \%$ of $17: 0 \nabla$ and $21 \%$ of $18: 1$. The percentage composition of fatty acids approached this value as exponential growth proceeded. Even when inocula of different fatty 
acid composition were used [e.g. samples taken during both exponential (Expt. no. 1) and postexponential (Expt. no. 2) phases of growth], the

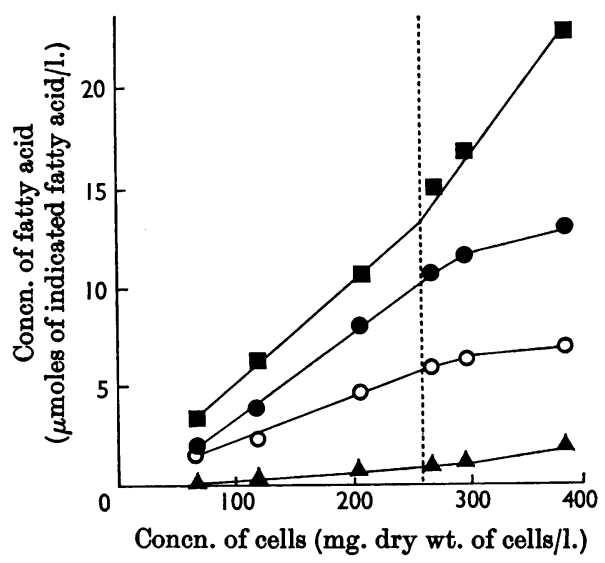

Fig. 4. Relationship between total indicated fatty acid/l. and cell density during growth in a sulphate-limiting medium: concentrations of $16: 1$ acid ( $(0), 16 \cdot 0$ acid (D), 17:0 $\nabla$ acid $(\Delta)$ and 18:1 acid $(O)$. The cells were grown in the fermenter at $37^{\circ}$ in a medium containing $54.4 \mathrm{~mm}$ glycerol, 45.2 mM-phosphate, $75.8 \mathrm{~mm}$-ammonia, $0.1 \mathrm{~mm}$ $\mathrm{Mg}^{2+}$ and sulphate $(0.05 \mathrm{~mm})$. Experimental details are described in the Materials and Methods section. The broken line at $260 \mathrm{mg}$./l. cell density indicates the end of exponential growth. The slope of the lines during exponential growth is the amount of each fatty acid synthesized/mg. of new cell material formed. composition by the end of the exponential phase was always similar (Table 2). A decrease in percentage of a fatty acid was a result of dilution by other newly formed fatty acid. Since $\Delta A / \Delta D$ for each fatty acid was constant during the exponential phase (where the S.G.R. is also constant), $q$ for each fatty acid, which is S.G.R. $\times(\Delta A / \Delta D)$, was also constant during the exponential phase (Figs. 5 and 6).

Post-exponential phase. The nature of the growthlimiting nutrient obviously had no effect on fatty acid synthesis in the exponential phase, but this was not so in the post-exponential phase. Observations during the post-exponential phase were continued for a convenient length of time which varied from experiment to experiment. Sometimes the stationary phase was soon reached and the cell density remained constant, whereas in other experiments the cells began to lyse. Frequently, growth continued at a decreasing rate for many hours and the experiment was stopped when convenient. In spite of these experimental differences, cyclopropane acid accumulation was greater when $\mathrm{SO}_{4}{ }^{2-}, \mathrm{Mg}^{2+}$ and glycerol were not growthlimiting (i.e. when $\mathrm{NH}_{4}{ }^{+}$or $\mathrm{PO}_{4}{ }^{3-}$ were made growth-limiting) (Table 3).

In conditions conducive to cyclopropane acid accumulation, 19:0 $\nabla$ appeared sometime during the post-exponential phase. The greater accumulation of cyclopropane acids when $\mathrm{NH}_{4}{ }^{+}$or $\mathrm{PO}_{4}{ }^{3-}$ were growth-limiting was reflected by a larger decrease in the percentage of unsaturated acids. There was always some accumulation of 16:0

Table 2. Changes in the fatty acid composition of the extractable lipid of E. coli during the exponential phase of growth at $37^{\circ}$

Composition of the growth medium was: $\mathrm{SO}_{4}{ }^{2-}, 0.75 \mathrm{~mm} ;$ glycerol, $54 \cdot 4 \mathrm{mM} ; \mathrm{PO}_{4}^{3-}, 44 \mathrm{mM} ; \mathrm{Mg}^{2+}, 0 \cdot 1 \mathrm{mM} ;$ growthlimiting $\mathrm{NH}_{4}{ }^{+}, 5 \mathrm{~mm}$. Two inocula of widely differing fatty acid composition were employed and samples were taken at the end of the exponential phase (435 mg. dry wt. of cells/l.); the fatty acids were examined (see Materials and Methods section). The inocula were prepared from cells growing in this growth medium at cell concentrations 373 and $660 \mathrm{mg}$. dry wt. cells/l. respectively.

\begin{tabular}{|c|c|c|c|c|}
\hline \multirow[b]{2}{*}{ Expt. no. } & \multirow[b]{2}{*}{ Fatty acid } & \multicolumn{2}{|c|}{ Fatty acid composition (\%) } & \multirow{2}{*}{$\begin{array}{l}\text { Metabolic quotient } \\
\text { (m } \mu \text { moles of } \\
\text { fatty acid } \\
\text { synthesized } / \mathrm{mg} \text {. } \\
\text { dry wt. of } \\
\text { cells } / \mathrm{hr} \text {.) }\end{array}$} \\
\hline & & Inoculum & $\begin{array}{c}\text { End of } \\
\text { exponential } \\
\text { phase }\end{array}$ & \\
\hline 1 & $\begin{array}{l}16: 1 \\
16: 0 \\
17: 0 \nabla \\
18: 1 \\
19: 0 \nabla\end{array}$ & $\begin{array}{r}20 \cdot 5 \\
\mathbf{3 6} \cdot \mathbf{1} \\
\mathbf{3 \cdot 5} \\
\mathbf{1 3 \cdot 5} \\
\mathbf{0}\end{array}$ & $\begin{array}{c}30 \cdot 5 \\
39 \cdot 5 \\
4 \cdot 0 \\
17 \cdot 5 \\
0\end{array}$ & $\begin{array}{r}30 \cdot 1 \\
37 \cdot 6 \\
3 \cdot 4 \\
14 \cdot 4 \\
-\end{array}$ \\
\hline 2 & $\begin{array}{l}16: 1 \\
16: 0 \\
17: 0 \nabla \\
18: 1 \\
19: 0 \nabla\end{array}$ & $\begin{array}{r}7 \cdot 5 \\
46 \cdot 3 \\
20 \cdot 5 \\
14 \cdot 5 \\
4 \cdot 5\end{array}$ & $\begin{array}{r}32 \cdot 5 \\
39 \cdot 0 \\
4 \cdot 0 \\
18 \cdot 0 \\
0\end{array}$ & $\begin{array}{r}32 \cdot 2 \\
36 \cdot 6 \\
3 \cdot 8 \\
16 \cdot 6 \\
-\end{array}$ \\
\hline
\end{tabular}


Table 3. Changes in the relative amounts of fatty acids during the post-exponential phase of growth in the presence of different growth-limiting nutrients

Summary of results from 22 experiments in which cells were grown at $37^{\circ}$ in the fermenter in glycerol-inorganic salts media (see the Materials and Methods section), with one of the constituents growth-limiting. Samples were taken at the end of the exponential phase and at the end of the experiment; this interval, the permitted duration of the post-exponential phase, was variable. The fatty acids of the extractable lipids were examined and the change in percentage of the individual fatty acids during the post-exponential phase was within the range shown in the Table. Group $a$, low accumulation of cyclopropane acids; group $b$, high accumulation of cyclopropane acids.

Range of increase or decrease of indicated fatty acid between the end of the exponential phase and the end of the experiment

\begin{tabular}{|c|c|c|c|c|c|c|c|}
\hline \multirow[b]{2}{*}{ Group } & \multicolumn{2}{|c|}{ Nutrient in medium } & \multicolumn{3}{|c|}{ Increase (\%) } & \multicolumn{2}{|c|}{ Decrease (\%) } \\
\hline & $\begin{array}{l}\text { growth. } \\
\text { limiting }\end{array}$ & non-limiting & $16: 0$ & $17: 0 \nabla$ & $19: 0 \nabla$ & $16: 1$ & $18: 1$ \\
\hline$a$ & $\begin{array}{l}\mathrm{SO}_{4}{ }^{2-} \text { or } \mathrm{Mg}^{2+} \\
\text { or glycerol }\end{array}$ & $\mathrm{PO}_{4}{ }^{3-}, \mathrm{NH}_{4}^{+}$ & $0-10$ & $<2 \cdot 5$ & 0 & $<8 \cdot 5$ & 0 \\
\hline$b$ & $\mathrm{PO}_{4}{ }^{3-}$ or $\mathrm{NH}_{4}+$ & $\begin{array}{l}\mathrm{SO}_{4}{ }^{2-}, \mathrm{Mg}^{2+} \\
\text { glycerol }\end{array}$ & $0-9 \cdot 5$ & $4-26$ & $0-5$ & 3-26 & $0-14 \cdot 5$ \\
\hline
\end{tabular}

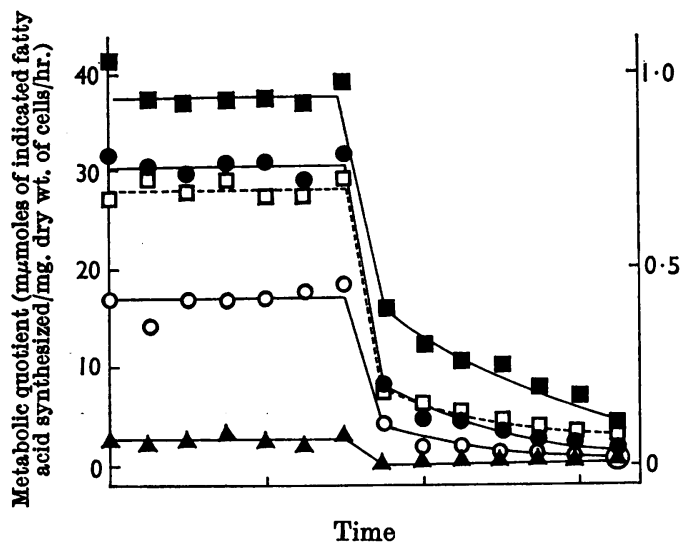

Fig. 5. Changes in the specific growth rate $(\square \cdots \square)$ and the metabolic quotient of the major fatty acids during growth in a sulphate-limiting medium: metabolic quotients for $16: 1$ acid $(\bullet), 16: 0$ acid $(\square), 17: 0 \nabla$ acid $(\Delta)$ and 18:1 acid (O). Each interval on the time scale represents $1 \mathrm{hr}$. Experimental details are given in Fig. 4.

during the post-exponential phase. This effect is illustrated in Fig. 4, where there was an increase (1.35-fold) in slope $(\Delta A / \Delta D$ for 16:0 rose from 53 to $72 \mathrm{~m} \mu \mathrm{moles} / \mathrm{mg}$. of new cell material formed) that reflected the increase in the percentage of 16:0. In some experiments this increase in slope more than doubled.

It is not possible to calculate the metabolic quotient $(q)$ in the post-exponential phase from the S.G.R. and $\Delta A / \Delta D$ values, since, unlike the situation in the exponential phase, the S.G.R. is falling

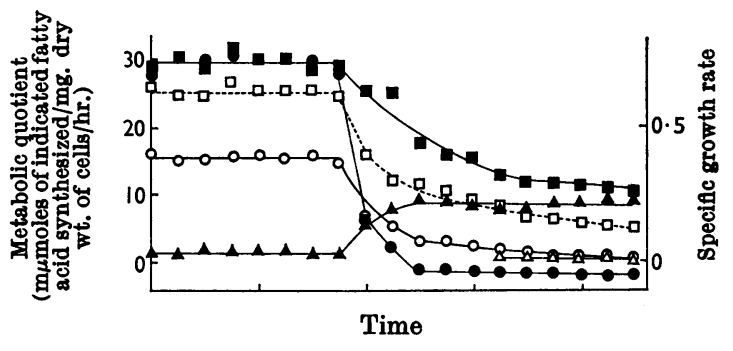

Fig. 6. Changes in the specific growth rate $(\square \cdots \square)$ and metabolic quotient of the major fatty acids during growth in a phosphate-limiting medium : metabolic quotients for 16:1 acid (৩), 16:0 acid ( $(\square), 17: 0 \nabla$ acid $(\Delta), 18: 1$ acid $(0)$ and 19:0 $\nabla$ acid $(\Delta)$. The medium contained $0.75 \mathrm{mM}^{-\mathrm{SO}_{4}}{ }^{2-}$, 54.4 mM-glycerol, $151.6 \mathrm{mM}^{-N_{4}}{ }^{+}, 0.1 \mathrm{~mm}-\mathrm{Mg}^{2+}$ and 0.33 mM-PO ${ }_{4}{ }^{3-}$. Each interval on the time scale represents $1 \mathrm{hr}$.

and $\Delta A / \Delta D$ may be changing. Therefore the metabolic quotient in the post-exponential phase was calculated from $(\Delta A / \Delta T) \times 1 / D_{m}$. The metabolic quotient for each fatty acid was calculated throughout the exponential and postexponential phases of growth, and the results were plotted against time. In an experiment in which conditions were not favourable for cyclopropane acid accumulation (Table 3, group $a$ ), within $15 \mathrm{~min}$. after the end of exponential growth, there was an abrupt fall in the S.G.R. (Fig. 5) and also in the metabolic quotients of all fatty acids. Subsequently $q$ for 17:0 $\nabla$ remained constant at onequarter of its former value, whereas the metabolic quotients for all other acids decreased still further. Consequently 17:0 $\nabla$ synthesis increased threefold 
from $1 / 30$ to $1 / 10$ of total fatty acid synthesis. The $q$ for 16:0 decreased proportionally less than $q$ for 16:1 or for 18:1. These changes resulted in an accumulation of $16: 0$ and a slight accumulation of 17:0 $\nabla$, since the change in percentage composition depends on the ratio of the metabolic quotients at any one time.

In an experiment in which cyclopropane acid accumulation was favoured (Table 3, group $b$ ), the rapid decrease in the S.G.R. when exponential growth ceased was again accompanied by abrupt decreases in $q$ for 16:1, 18:1 and 16:0 (Fig. 6). In contrast, $q$ for 17:0 $\nabla$ increased sevenfold from 1.3 to $9 \mathrm{~m} \mu \mathrm{moles} / \mathrm{mg}$. dry wt. of cells $/ \mathrm{hr}$. and remained constant. After $90 \mathrm{~min}$. in the post-exponential phase, 19:0 $\nabla$ appeared $(0.8 \mathrm{~m} \mu \mathrm{mole} / \mathrm{mg}$. dry wt. of cells $/ \mathrm{hr}$.). After $1 \mathrm{hr}$. in the post-exponential phase $q$ for $16: 1$ became negative (i.e. there was a net disappearance of 16:1). As in Fig. 5, $q$ for 16:0 decreased less rapidly than for 16:1 and 18:1. In the post-exponential phase (until the end of the experiment), synthesis of $17: 0 \nabla$ increased from 1/40 to almost a half of total fatty acid synthesis, whereas synthesis of 16:0 increased from 2/5 to nearly a half. These changes resulted in some increase in the percentage of $16: 0$ and a large increase in the percentage of $17: 0 \nabla$ in the total fatty acids during this period.

Requirement for $\mathrm{SO}_{4}^{2-}, \mathrm{Mg}^{2+}$ and glycerol for cyclopropane acid formation by resting cells. Cells were grown in phosphate-limiting media until they had been in the post-exponential phase of growth for

Table 4. Requirement for $\mathrm{SO}_{4}{ }^{2-}, \mathrm{Mg}^{2+}$ and glycerol for the formation of 17:0 $\nabla$ by non-growing cells of E. coli

Cells were grown in a medium in which $\mathrm{PO}_{4}{ }^{3-}$ was the growth-limiting nutrient until they had been in the postexponential phase of growth for $50 \mathrm{~min}$. (see the Materials and Methods section). Samples of the harvested cells were incubated in swirled flasks at $37^{\circ}$ for $5 \mathrm{hr}$. in a medium with final concentrations of $45 \mathrm{~mm}$-imidazole-HCl buffer $(\mathrm{pH} 7 \cdot 0)$, $0.33 \mathrm{~mm}-\mathrm{MgCl}_{2}, 1.8 \mathrm{mM}_{-} \mathrm{SO}_{4}{ }^{2-}$ and $20 \mathrm{~mm}$-glycerol from which components were omitted as indicated. The fatty acids of the extractable lipid were analysed by gas chromatography.

Composition of the incubation medium

$\mathrm{SO}_{4}^{2-}, \mathrm{Mg}^{2+}$ and glycerol omitted

$\mathrm{SO}_{4}^{2-}, \mathrm{Mg}^{2+}$ and glycerol omitted

$\mathrm{SO}_{4}{ }^{2-}$ and $\mathrm{Mg}^{2+}$ omitted

$\mathrm{Mg}^{2+}$ and glycerol omitted

Complete system
Percentage of 17:0 $\nabla$

Time of incubation (hr.)

0 fatty acids 10.5

5

$8 \cdot 6$

5

5

5 50min. By this time $q$ for 17:0 $\nabla$ had risen to $9 \mathrm{~m} \mu$ moles of 17:0 $\nabla / \mathrm{mg}$. dry wt. of cells/hr. (Fig. 6). To test whether non-growing cells formed cyclopropane acids, these cells were incubated with glycerol, $\mathrm{SO}_{4}{ }^{2-}$ and $\mathrm{Mg}^{2+}$, but the other essential nutrients for growth $\left(\mathrm{NH}_{4}{ }^{+}\right.$and $\mathrm{PO}_{4}{ }^{3-}$ ) were not added. Table 4 shows that resting cells were able to make cyclopropane acid but that they were unable to do so in the absence of glycerol, $\mathrm{Mg}^{2+}$ and $\mathrm{SO}_{4}{ }^{2-}$, $\mathrm{Mg}^{2+}$ and glycerol, or $\mathrm{SO}_{4}{ }^{2-}$ and $\mathrm{Mg}^{2+}$.

\section{DISCUSSION}

The fatty acid composition of $E$. coli is known to be affected by certain changes in growth conditions (e.g. temperature, pH, medium composition and age of culture). The proportions of monoenoic acids to cyclopropane acids vary most of all; cells at the end of growth had a greater proportion of cyclopropane acids than cells from earlier stages. A greater understanding of these changes in fatty acid metabolism has resulted from measurements of the metabolic quotient for each acid. As long as the cells grew exponentially the metabolic quotient for each acid was constant and hence the newly synthesized lipid had a constant composition. The composition of this new lipid was unaffected by the composition of the glycerol-inorganic salts medium.

The transition from exponential growth to postexponential growth was very significant because the pattern of fatty acid synthesis changed abruptly. This change in fatty acid synthesis was most noticeable in the monoenoic acids (especially 16:1). In the phosphate-limiting medium (Fig. 6), $q$ for 16:1 had fallen to one-fifth of its exponential phase value within $15 \mathrm{~min}$. of the end of the exponential phase, even though the growth rate had fallen only to two-thirds. Similar effects were found with all other growth-limiting nutrients tested, suggesting that this fall was a general effect associated with the end of exponential-phase metabolism. Although the mean generation time of the cells was $1 \mathrm{hr}$., the change in metabolic quotients of the fatty acids occurred within a few minutes.

In the post-exponential phase of growth, the metabolic quotients of the fatty acids were no longer constant but changed as growth decreased, each acid behaving in a different manner. Whereas cells growing exponentially obtained adequate supplies of all essential nutrients, this condition did not apply in the post-exponential phase and fatty acid metabolism was affected as the growth-limiting nutrient became depleted. Cyclopropane acid accumulated, but unless adequate amounts of glycerol, $\mathrm{SO}_{4}^{2-}$ and $\mathrm{Mg}^{2+}$ ions were supplied, the increase was slight. In conditions not conducive to cyclopropane acid formation, the metabolic quotients of all fatty acids fell but that of 17:0 $\nabla$ 
least of all, so that there was a small accumulation of 17:0 $\nabla$. Conditions conducive to cyclopropane acid formation occurred when either phosphate or ammonia was growth-limiting. Where cells were grown in a limited supply of sulphate (Fig. 1), presumably most of the sulphate was converted into protein and only a minimal amount was available for other purposes such as cyclopropane acid formation from $S$-adenosylmethionine. There was always some cyclopropane acid synthesized (about $5 \mathrm{~m} \mu$ moles of 17:0 $\nabla / \mathrm{mg}$. dry wt. of cells). In the post-exponential phase, protein formation was less active, and possibly more sulphate was available for cyclopropane acid formation. In conditions conducive to cyclopropane acid formation, $q$ for 17:0 $\nabla$ either remained constant or increased as much as sevenfold. This supports the suggestion by Law et al. (1963) that cyclopropane acid synthesis during the late exponential and stationary phases of growth proceeds at the same, or possibly accelerated, rate as during the early exponential phase. The growth-limiting concentration of $\mathbf{M g}^{2+}$ ions does not allow for any appreciable formation of cyclopropane acid (Fig. 3). It was not possible to show any requirement for $\mathrm{PO}_{4}{ }^{3-}$ or $\mathrm{NH}_{4}{ }^{+}$ions in cyclopropane formation, but there may have been enough of these substances in the cells.

Knivett \& Cullen (1965) reported a formation of cyclopropane acids two or three times greater in stationary-phase cultures grown in flasks than in cultures grown in the fermenter at the same $\mathrm{pH}$. It was suggested that the difference may have been due to the degree of aeration, but this difference could now be attributed to the length of time the cells remained in the stationary phase continuing to synthesize cyclopropane acids. The flask-grown cultures had remained in the stationary phase for an unknown length of time, whereas the fermenter cultures were harvested when growth ceased, and were not long in the stationary phase.

We are grateful to Mr M. Jackson for technical assistance. We thank Dr and Mrs D. M. Herbert for helpful discussion of the mathematical treatment.

\section{REFERENCES}

Croom, J. A. \& MoNeill, J. J. (1961). Bact. Proc. p. 170.

Herbert, D., Elsworth, R. \& Telling, R. C. (1956). J. gen. Microbiol.14, 601.

Hildebrand, J. G. \& Law, J. H. (1964). Biochemistry, 3, 1304.

Karkas, J. D., Türler, H. \& Chargaff, E. (1965). Biochim. biophys. Acta, 111, 96.

Kates, M., Adams, G. A. \& Martin, S. M. (1964). Canad. J. Biochem. 42, 461.

Knivett, V. A. \& Cullen, J. (1965). Biochem.J.96, 771.

Law, J. H., Zalkin, H. \& Kaneshiro, T. (1963). Biochim. biophys. Acta, 70, 143.

Marr, A. G. \& Ingraham, J. L. (1962). J. Bact. 84, 1260.

Monod, J. (1949). Annu. rev. Microbiol. 8, 371. 